\title{
Project Based Learning (PjBL) Practices at Politeknik Kota Bharu, Malaysia
}

\author{
Md. Baharuddin Haji Abdul Rahman \\ Department of Mechanical Engineering, Politeknik Kota Bharu, Km 24 \\ Pangkal Kalong, 16450 Ketereh, Kelantan, Malaysia \\ Tel: 60-19-902-1484 E-mail: mbaharuddin@oum.edu.my \\ Khairul Azhar Mat Daud \\ Department of Mechanical Engineering, Politeknik Kota Bharu, Km 24 \\ Pangkal Kalong, 16450 Ketereh, Kelantan, Malaysia \\ Tel: 60-19-933-3919 E-mail: khairulazhar.pd07@student.usm.edu.my
}

Kamaruzaman Jusoff (Corresponding author)

Faculty of Forestry, Universiti Putra Malaysia, 43400 Serdang, Selangor, Malaysia

Tel: 60-3-8946-7176_E-mail: kjusoff@yahoo.com

Nik Azida Abd Ghani

Department of Commerce, Politeknik Kota Bharu, Km 24, Pangkal Kalong, 16450 Ketereh

Kelantan, Malaysia

Tel: 60-19-933-7550_E-mail: nikazida5@yahoo.com

This project is funded by Universiti Sains Malaysia (sponsoring information)

\begin{abstract}
This study explores the utilization of Project-based Learning module in the subject of project development for the Mechanical Engineering students at Politeknik Kota Bharu. This study focuses on the development of the PjBL module based on socio-constructivist approach. The objective of this study is to explore the influence of the utilization of the PjBL module on students' meta-cognition, motivation and self regulation. Result shows that the overall engineering students reported higher level of motivation, self confidence and self regulation throughout the process. The PjBL also enhances the cognitive and critical thinking in engineering problem solving among students. The use of PjBL module enables students to plan their project easily, work collaboratively with peers with minimal supervision from supervisors or lecturers and successfully complete their project on time. The positive feedback from this study may be used by management to further apply this PjBL concept across disciplines and departments.
\end{abstract}

Keywords: Project based learning, Polytechnic, Engineering, Practices

\section{Introduction}

Project management is a subject that is compulsory to be undertaken by students enrolled under the Mechanical Engineering Department, Polytechnics, Malaysia Ministry of Higher Education. This subject carries J5012 as its subject code. In conjunction with the current technological advances, a new approach to teaching and learning has been developed specifically for this subject. This new approach that utilizes the concept of project-based learning method aims to provide students with the necessary knowledge and information pertaining to the subject. The traditional method of instruction may not be sufficient to meet the needs of the dynamic subject to comply with the international engineering standards. Project-based learning $(\mathrm{PjBL})$ should replace the traditional method of instruction (Dori, 2000) in the effort to improve the quality of graduates. The internal researcher and developer should develop $\mathrm{PjBL}$ to fulfill the needs of technical institutions to produce engineering graduates and better facilitate the creation of innovative products (Moursund, 2002; Thomas et al., 1999) suitable for industry.

The establishment of polytechnics is a part of government policy to produce semi-skilled workers to fulfill the needs of local industries. These workers should also possess the soft skills needed in the working environment and meet the 
engineering standards. Polytechnics should find new teaching and learning methods to adapt to the dynamic needs of the industries. The PjBL concept is applied to the project management subject and provides better stage-by-stage supervision of engineering students and facilitates the development of innovations that meet the international engineering standards. This PjBL module developed support Dewey, Papert and others, the advocates of learning from projects rather than from isolated problems. PjBL concept enables engineering students to face the task of formulating their own problems, guided by the general goals they set, the 'interesting' phenomena and difficulties they discover through their interaction with the environment (Collins et al., 1989).

The PjBL module was introduced to the Mechanical Engineering students taking the project development subject at Politeknik Kota Bharu. This module is central to the notion of socio-constructivism and other related activity-based approaches. Under the PjBL module, students are expected to formulate their own problems and set their own goals. The goals they set as well as the unexpected discoveries they will make during their interaction with the real works environment serve as guides (Collins et al, 1989). It is therefore important to divide scenarios into sequences and to divide problems into sub-problems via PjBL module (task by task by using standard PjBL forms guide) so that each group of project development performs only one task at a time (weekly progress) and that these tasks are flexible enough for engineering students to complete them whatever their level of engineering work progress. Project-based learning $(\mathrm{PjBL})$ is a model which differs from traditional teaching since the focus is put on the learner and his project. Learners have the opportunity to work more autonomously and build their knowledge.

PjBL module provides standardized procedures for team projects. This module facilitates the development of innovative products or projects. This PjBL module was developed and first introduced in Politeknik Kota Bharu, hence being a pioneer among polytechnics and community colleges at Malaysia. It grows up for the starting point with same process occurring at U.S generated with their developers such John Dewey and William H. Kilpatrick (Synteta, $2001 ; 2002 ; 2003)$. The project method in PjBL module is a genuine learning process of producing innovative products at the Mechanical Engineering Department, Politeknik Kota Bharu in relation to the dynamic engineering education advances. The advantages of PjBL concept was described in detail and definitively delimited for the first time by William Heard Kilpatrick in his essay, "The Project Method," which became known worldwide (Wilson et al., 2001).

Rooted (at least its design of the curriculum, instruction and assessment) in various constructivist schools of thought (Synteta, 2003), constructionist (Morsund 2002; Thomas et.al., 1999), cooperative or collaborative learning (Dillenbourg et al., 20002, and generally active learning, has strong theoretical support for successful achievement. Still, we have to note that $\mathrm{PjBL}$ is not a pure constructivist model but uses also multiple methods of instruction, among them direct, explicit, (didactic) instruction (Markham et.al., 2003). PjBL can be found under the name of project method, project approach, knowledge in action, learning or education by project, intentional learning (Thomas, 2000), learning by doing, and design experiments (Barron, 1998), to name a few.

Project Based Learning (PjBL) module is a teaching procedure and learning model (curriculum development and instructional approach based on BIE approach) that emphasizes student-centered instruction by assigning innovative projects design and development. It allows engineering students to work more autonomously to construct their own learning, and culminates in realistic, student-generated products. More specifically, project-based learning focuses on the central concepts of engineering discipline. It also engages learning and technical experiences that involve students in complex, real-world projects through which they develop and apply skills and knowledge. In addition, project-based learning requires students to draw from many information sources and disciplines in order to solve technical and vocational problems. PjBL is also a learning in which curricular outcomes can be identified up-front, but in which the outcomes of the student's learning process are neither predetermined nor fully predictable to produce innovative engineering product. Meanwhile, Moursund (2002) and Thomas (2000) defined PjBL as an advance engineering experiences through which students learn to manage and allocate resources such as time and materials. Project-based learning $(\mathrm{PjBL})$ module focuses mostly on a production model which incorporates the steps required to produce innovative products successfully, namely defining the purpose of creating the end-product, identifying their innovative product to produce, researching the topic, designing the product, managing the project, solving the technical and vocational problems that arise, completing the making of the product, and performing self-evaluation and reflection (Schneider, 2005).

So, the driving force is the end-product, but the key to success is the skills acquired during its production.

The PjBL module was designed based on various socio-constructivist technical institutions of thought (Bruner, 1973), but can also be found in other modern instructional theories (Ausubel et al., 1978; Reigeluth, 1999). Socio-constructivism is an understanding of learning that stresses the importance of constructing knowledge based on previous knowledge and interaction with the social environment, based on theories of constructivism (Piaget), socio-culturalism and situated learning (Lave and Wenger, 1991). Socio-constructivism has been perceived as a set of pedagogies which use strategies like project-based learning (Thomas et al., 1999), problem, inquiry or action learning. Each of these designs has different pedagogical objectives. Good pedagogical designs should include somewhat 
structured pedagogical scenarios while lecturer's or supervisor's role is crucial. In this perspective, the modern teacher has to perform the roles of a facilitator, manager and orchestrator. He needs adequate supporting environments since such designs can become very complex and costly. Therefore, the objective of this study is to evaluate the effectiveness of PjBL module in developing the meta-cognition, motivation and self-regulation of Mechanical Engineering students in project development.

\section{Methods and materials}

\subsection{Model development}

During the development of this PjBL module, developers focus on the powerful pedagogical designs. The PjBL concept aims at the development of general problem-solving skills, deeper conceptual understanding and more applicable knowledge (van Merriënboer et al., 2003). These include the application of complex, realistic and challenging engineering problems that elicit active and constructive processes of knowledge and skill acquisition in engineering students. The PjBL module should facilitate the participation of small group or encourage collaborative work and provide ample opportunities for interaction, communication and co-operation. The PjBL module encourages engineering students to set their own goals and provides guidance to students in taking more responsibility for their own technical and vocational learning activities. Project-based learning $(\mathrm{PjBL})$ focuses on the learning process of the project teams. PjBL concept enables smooth implementation of engineering problem solving process (Dym and Little, 2004). With PjBL concept, more students are engaged in their learning style. These students work collaboratively to ensure the overall process conforms to the standards provided in the PjBL module. Supervisors or lecturers play their parts as tutors or mentors to ensure that the process runs smoothly.

Self Directed Learning (SDL) component works further enhance the effectiveness of the PjBL module developed (Figure 1). This SDL acts as a catalyst to facilitate self directed learning in engineering students involved in project development. Furthermore, SDL motivates them to complete the project successfully on time. Both SDL and PjBL enable students to be independent and capable of self learning without direct supervision from supervisors or lecturers (Shapiro, 1994). The PjBL module development incorporates student centered learning process in producing innovative product with minimal supervision. The principles and model of PjBL module followed the suggestion of Barron (1998). Figures 2, 3a, 3b, 3c and 4 illustrate the development of PjBL concept, namely:

\section{Phase 1: Module planning, designing and drafting.}

The module was pilot tested for a period of six month. Based on the findings and responses from respondents, the module was redesigned to incorporate some added value to the PjBL module.

\section{Phase 2: Testing the effectiveness of the module.}

In this phase, two groups or team projects were selected as sample to test the effectiveness of the PjBL module. The responses from the two groups were collected as data to evaluate the module with the study objectives.

The project management subject utilizes standardized forms provided by the PjBL module. These guided PjBL forms generate consistently and process monitoring by weekly progress. The forms embedded in the module includes: Form P001 - Project discussion and proposal, Form P002 - Project sketches and design, Form P003 - Supervisor's review and confirmation, Form P004 - Final technical project design and making methods, Form P005 - Project planning of each stage development and fabrication process, Form P006 - detailed drawings for each component measurement and workshop fabrication methods., Form P007 - project procedures and fabrication methods, Form P008 - writings of each team member for workshop selection that conforms to the standard planning form (P005). Each process should be drafted consistently at each stage to avoid delays. The other forms are Form P008 - provide inputs for machines selection and present the calculation sheet for each components of the product making, Form P009 - final design of additional component and testing, Form P010 - evaluation and confirmation form for the components, Form P011 evaluation and testing of any added value or component to innovative products produced and finally Form P012 submission and evaluation of the power point for final presentation.

The roles of actors are also particular in PjBL module development. Project-based learning module is structured to transform teaching from "lecturers/supervisors telling" to "engineering students doing". Engineering students become active problem-solvers, and effective decision-makers rather than passive listeners. They collaborate or cooperate in groups, organize their activities, conduct research, solve problems, synthesize information, organize time and resources and reflect on their learning. Teachers change their role "from sage on the stage to guide on the side" and assume the role of cognitive and meta-cognitive coach (by asking, monitoring, probing, managing, group regulating, keeping moving) rather than knowledge-holder and disseminator. Project serves as the initial challenge and motivation (appealing to be explored, setting up the context of learning). The monitoring and evaluation of this project development subject is monitored through PjBL forms and this provides weekly marks on the progress of the project teams. The formative (weekly progress evaluation) and summative (final report evaluation) assessment facilitate the successful attainment of the project objectives (Wilkerson, 1995). 
In accordance with the innovative approach to learning, PjBL module also requires an innovative approach for the challenging task of assessment. It requires continuous and frequent assessment and include assessment from supervisors and peers, as well as self-assessment and reflection on the progress of the project.

\subsection{Pilot test of PjBL module}

The pilot test for this study takes a period of six months, after which the module was amended based on the findings especially on the problems and objectives of the study. This PjBL module which incorporates the use of PjBL forms guide the students with task by task process for the project development subject. Consistent monitoring and continuous evaluation facilitate the making of innovative products. This PjBL module was developed based on BIE project based learning concept. In team project development via PjBL concept, engineering students generate technical problem solving by entering each stage of project producing process. Collaborative activities are carried out throughout the period. At the same time, supervisors monitor the students' progress by following the task by task PjBL module guide. This new teaching method is able to match the needs of the project development need with the available equipments and resources.

Respondents for the pilot study comprised final semester students of Diploma in Automotive who utilize the PjBL module for the project development subject. These respondents have also entered some basic information such as other basic engineering syllabus, engineering workshop information and guides. These respondents are familiar with the use of hand tools, engineering design (Acad, Pro-Eng etc.) and automotive workshop. They have also undergone a six months practical training in industries. Based from an input data survey from the respondents, a lot of internal motivation and external skills have been identified during the developmental stage of the PjBL concept. By using PjBL module, planning becomes easy to them as their understanding of the project planning procedure for workshop improved in the process of entering the information into the module. Overall, the students said that their self-confidence and conformance to regulations and procedures increase when they utilize the PjBL module.

\section{Results and discussion}

The following are the salient points of the students' outcome during the interview.

"We have fun and confidence when we use this PjBL module for our project development. It works smoothly with a nice guided and totally easy to understand and highly motivated us to directly go further and on schedule. Overall process is covered with this PjBL module and generates full internal and external motivation". After understanding PjBL concept and using PjBL module, our project planning becomes easy, progresses and completed on time. Our self-confidence and self-regulation increases. The process that covers overall stages helps us in doing engineering works easily with confidence. PjBL forms helps us to generate our ideas on paper easily, at the same time there are improvements on the project management and development. At the beginning, we never thought that this PjBL Module ease us to produce innovative project on time and enable us to successfully work within the engineering standards. Going through such a cognitive experience with this PjBL module, it helps us a lot in the technical problem solving. Our knowledge in exploring new engineering product increases. This PjBL module helps us to get involved in engineering critical thinking and always generate alternative problem solving throughout the process".

Researchers have investigated the impact of project-based learning ( $\mathrm{PjBL}$ ) and related instructional approaches in a wide variety of engineering educational contexts ranging from automotive course, agriculture course to mechatronic course. These approaches have generally been shown to be effective in increasing students' motivation by engaging them in their own learning, in improving student problem-solving and higher order thinking skills (Mergendoller et al. 2003). It promotes meta-cognition and self-regulated learning by asking students to generate their own strategies for problem definition, information gathering, data-analysis, and hypothesis-building and testing, comparing these strategies against and sharing them with other students' and mentors' strategies. Teaching with the project-based learning method enables engineering students to work cooperatively with peers and supervisors in a student-centered environment where learners are encouraged to explore various topics of interest. The collaborative nature of the investigation enhances all of these valuable experiences as well as promotes a greater appreciation for social responsibility (Synteta, 2003). Hence, it also provides opportunities for interdisciplinary learning by engaging engineering students in applying the content of different subject areas during the various phases of the project. PjBL helps polytechnic students develop real world skills like the ability to collaborate well with others, make decisions and take initiative, and face complex problems. After completing a project, students are asked to create a self-evaluation of the project, like writing a meta-report. This enables the students to focus on their learning process and allows them to see their progress. Self-evaluation gives students a sense of accomplishment and further instills responsibility for engineering learning and by documenting the learning and project development process it also makes it easy to distribute marks to the end of presentation, with all the obvious advantages.

\section{Conclusion}

The PjBL module applied to project development in the Mechanical Engineering Department have some impact on the motivation, self confidence and conformity to regulation in students. The PjBL module allows consistent monitoring 
and continuous evaluation of students' progress in project development. The use of PjBL module enables students to plan their project easily, work collaboratively with peers with minimal supervision from supervisors or lecturers and successfully complete their project on time. It is suggested that future work should look into a particular instructional design issue dealing in a bigger project-oriented classes for an innovative product development with a high technical expectations.

\section{References}

Ausubel, D., Novak, J. \& Hanesian, H. (1978). Educational Psychology : A Cognitive View, (2nd Ed.), New York, Holt, Rinehart and Winston.

Bruner, J. (1973). Going Beyond the Information Given, New York, Norton.

Barron, B. (1998). Doing with understanding: Lessons from research on problem- and project-based learning'. Journal of the Learning Sciences.

Collins, A., Brown, J. S. and Newman, S. E.. (1989). Cognitive apprenticeship : Teaching the crafts of reading, writing, and mathematics. In L.B. Resnick (Ed.), Knowing, Learning, and Instruction: Essays in Honor of Robert Glaser, Hillsdale, NJ, Lawrence Erlbaum Associates.

Dori, Y.J. (2003). From nationwide standardized testing to school-based alternative embedded assessment in Israel: Students' performance in the Matriculation 2000 project. Journal of Research in Science Teaching.

Dillenbourg, P., D. Schneider \& Synteta, V.. (2002). Virtual learning environments. In Proceedings of The 3rd Congress on Information and Communication Technologies in Education, Rhodes, Kastaniotis Editions.

Dym, C. L., \& Little, P. (2004). Engineering Design: A Project-Based Introduction. (2nd ed.), Wiley

Lave, J. \& Wenger, E.. (1991). Situated Learning: Legitimate Peripheral Participation. Cambridge, UK, Cambridge University Press.

Mergendoller, J. R. \& Thomas, J. W. (2003). Managing Project Based Learning: Principles from the Field. The Buck Institute for Education,

Morsund, D. (2002). Project-based learning: Using Information Technology. (2nd edition), ISTE.

Markham, T. (2003). Project Based Learning Handbook. Buck Institute for Education,

Reigeluth, C.M. (1999) (Ed.). Instructional-Design Theories and Models: A New Paradigm of Instructional Theory. Mahwah, NJ: Lawrence Erlbaum Associates. Note: It seems that a new volume is under preparation (D. Schneider 12:45, 13 May 2006 (MEST)).

Schneider, D. (2005). Gestaltung kollektiver und kooperativer Lernumgebungen" in Euler \& Seufert (eds.), E-Learning in Hochschulen und Bildungszentren. Gestaltungshinweise für pädagogische Innovationen, München: Oldenbourg.

Shapiro, B. L. (1994). What Children Bring to Light: A Constructivist Pespective on Children's Learning in Science. New York: Teachers College Press.

Synteta, P. (2001). EVA_pm: Design and Development of a Scaffolding Environment for Students Projects. Unpublished Master thesis, University of Geneva, Geneva, Switzerland.

Synteta, P. (2002). Project-Based e-Learning: The model and the method, the practice and the portal. Unpublished PhD proposal (Accepted Oct, 2002). University of Geneva, Geneva, Switzerland.

Synteta, P. (2003). Project-Based e-Learning in higher education: The model and the method, the practice and the portal. Studies in Communication, New Media in Education. pp. 263-269.

Thomas, J. W., Mergendoller, J.R., \& Michaelson, A. (1999). Project-based learning: A handbook for middle and high school teachers. Novato, CA: The Buck Institute for Education.

Thomas, J. W. (2000). A review of research on project-based learning.

van Merriënboer, J.G. \& Pass, F.. (2003). Powerful learning and the many faces of instructional design : Toward a framework for the design of powerful learning environments. In E. De Corte, L. Verschaffel, N. Entwistle and J.G. van Merriënboer (Eds), Powerful Learning Environments : Unraveling Basic Components and Dimensions, Amsterdam, Pergamon.

Wilson, B. \& Lowry, M. (2001). Constructivist learning on the Web. In L. Burge (Ed.), Learning Technologies : Reflective and Strategic Thinking, San Francisco, Jossey-Bass, New Directions for Adult and Continuing Education.

Wilkerson, L., (1995). Introduction, tutors and small Groups in Problem-Based Learning: Lessons from the Literature. New Direction for Teaching and Learning. 


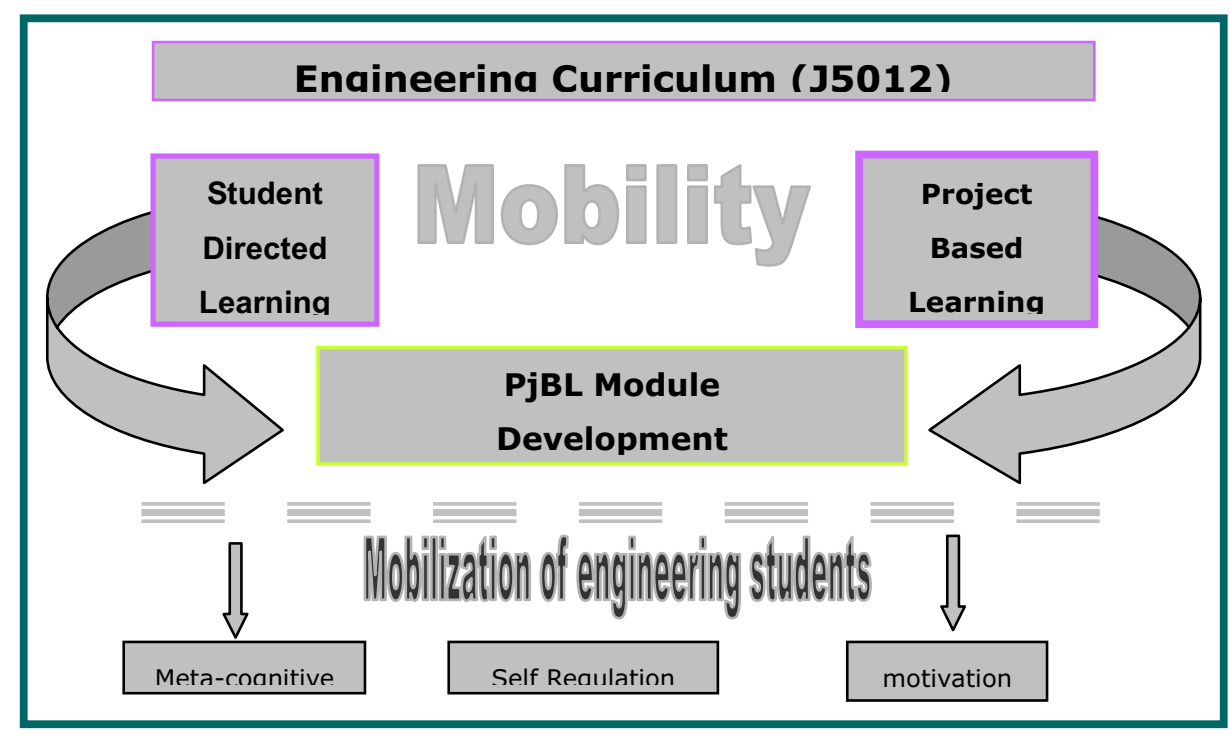

Figure 1. Model of PjBL Module Development

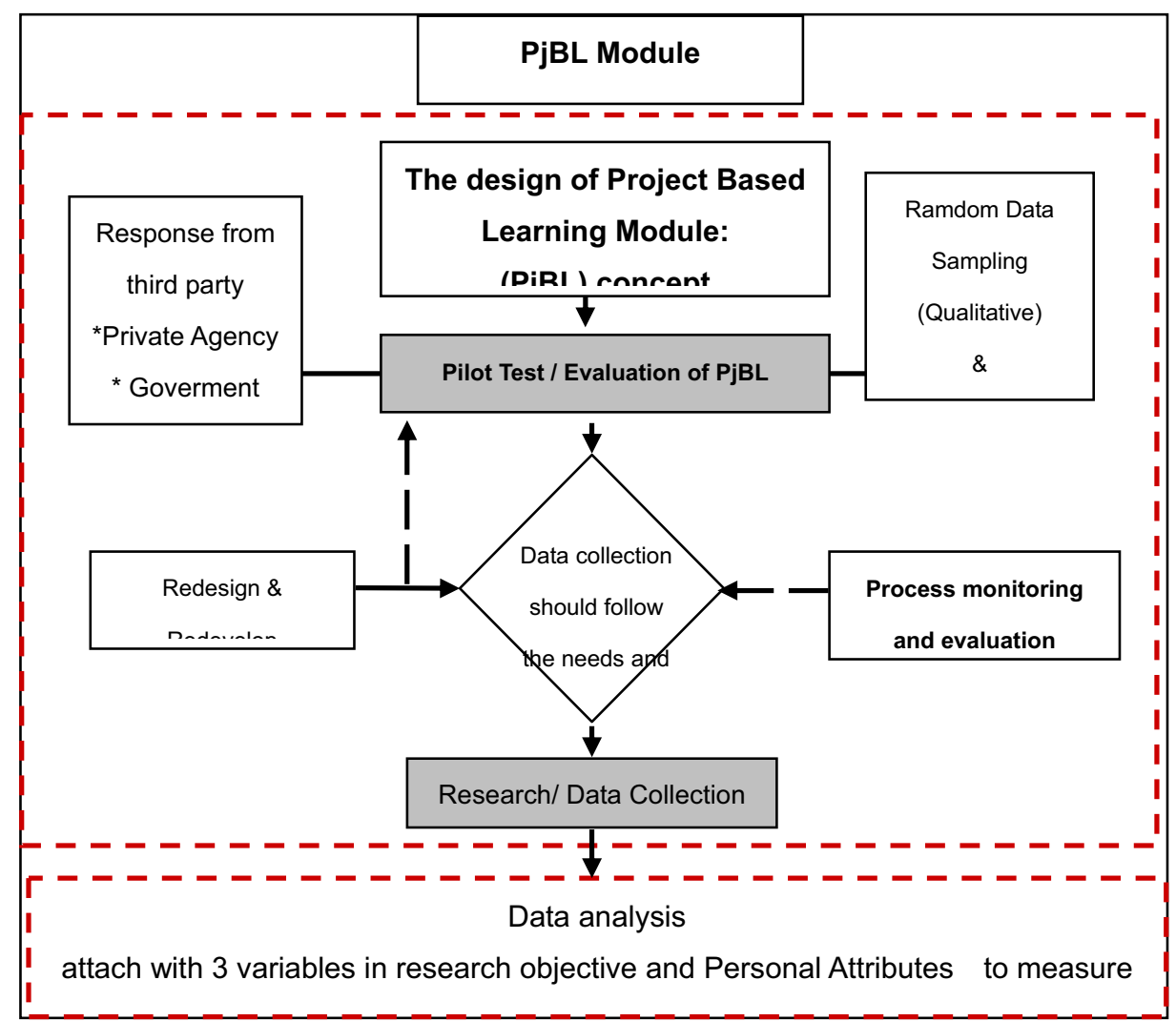

Figure 2. Methods for PjBL module development 


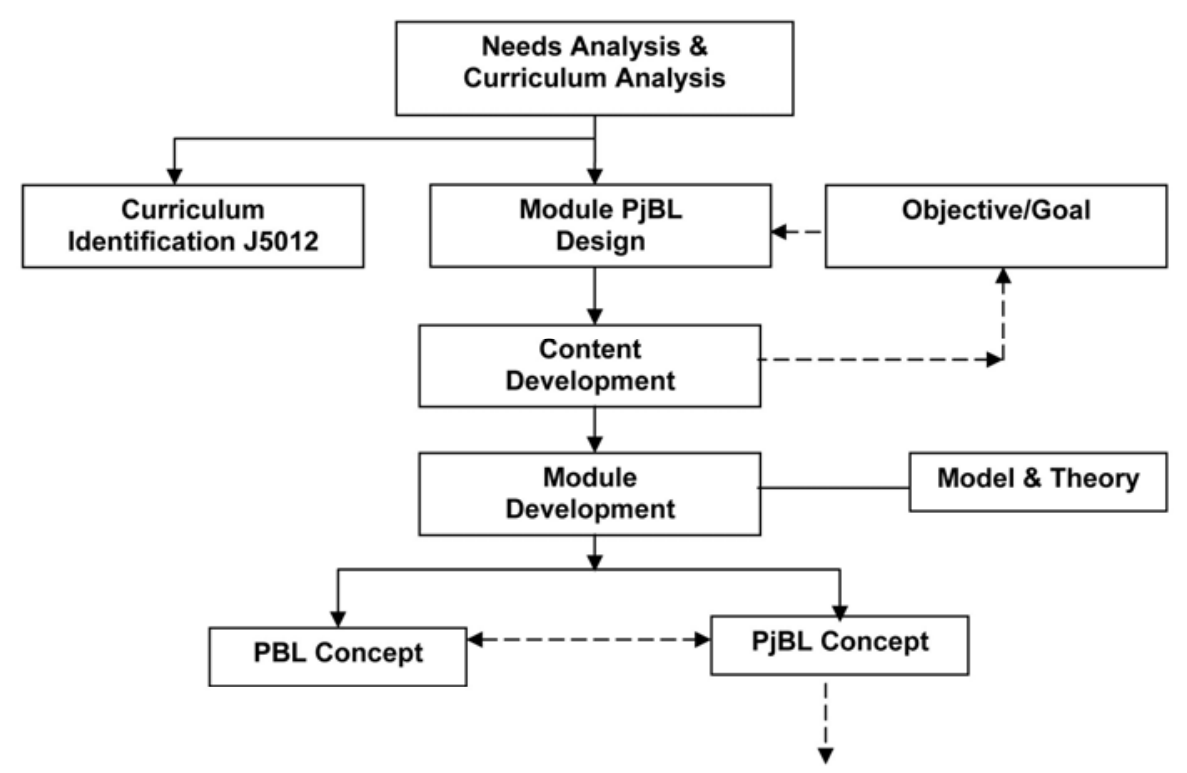

Figure 3a. Phase PjBL module development

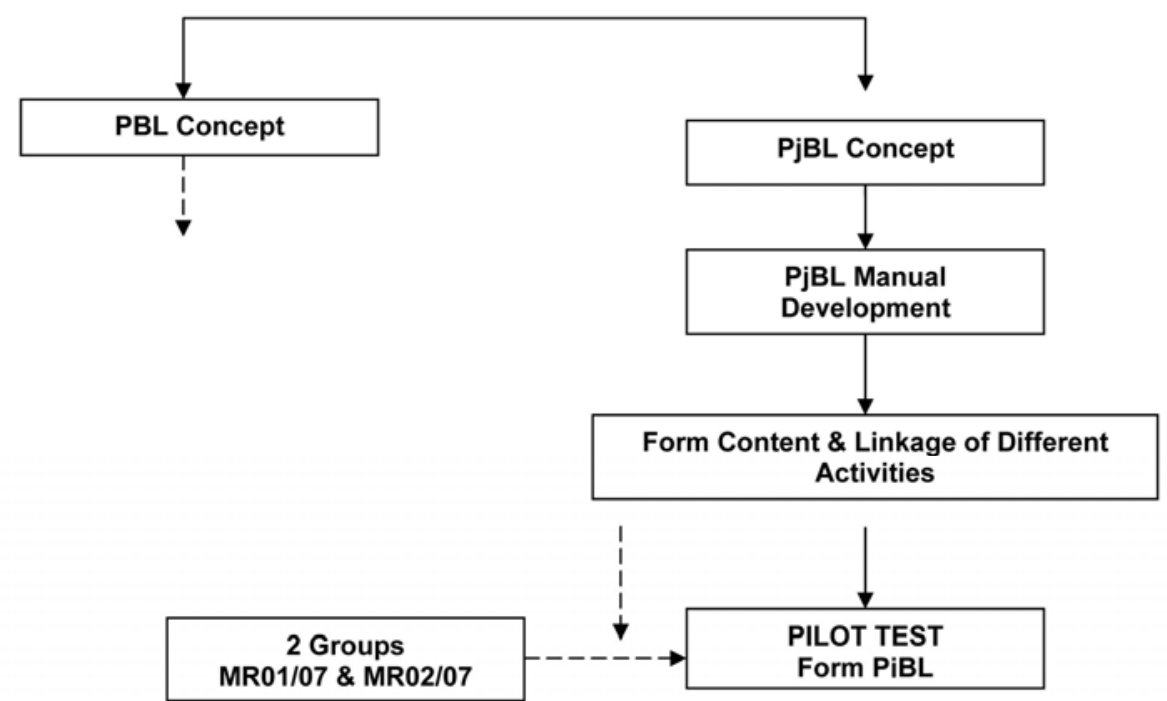

Figure 3b. Phase PjBL module development 


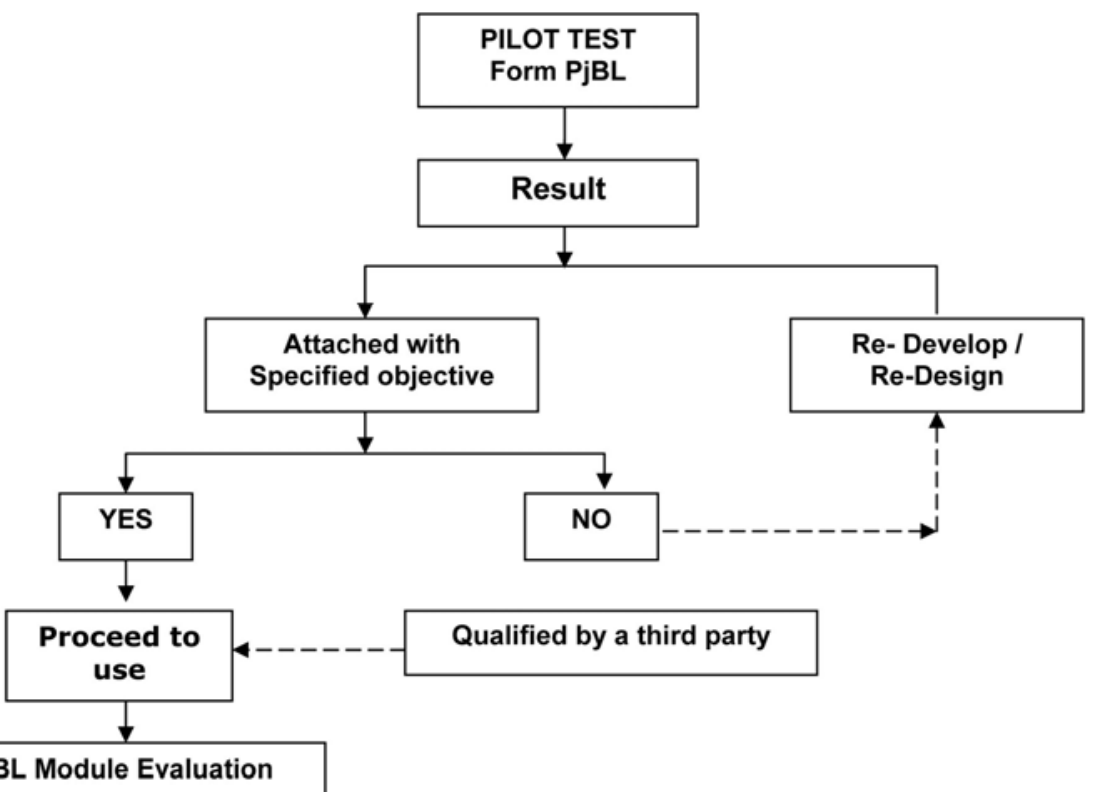

Figure 3c. Phase PjBL module development

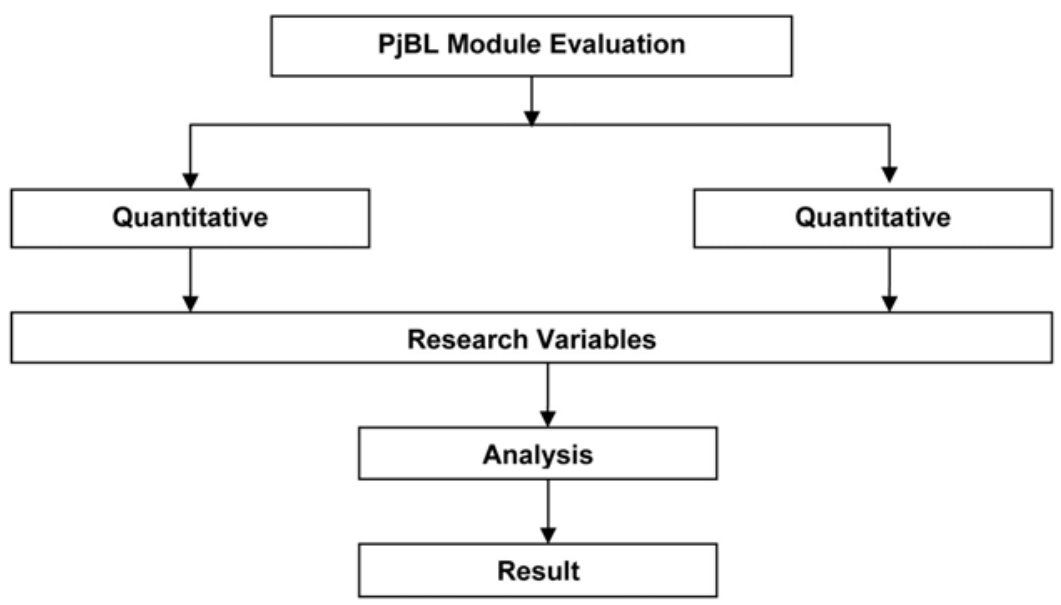

Figure 3d. Phase PjBL module development 


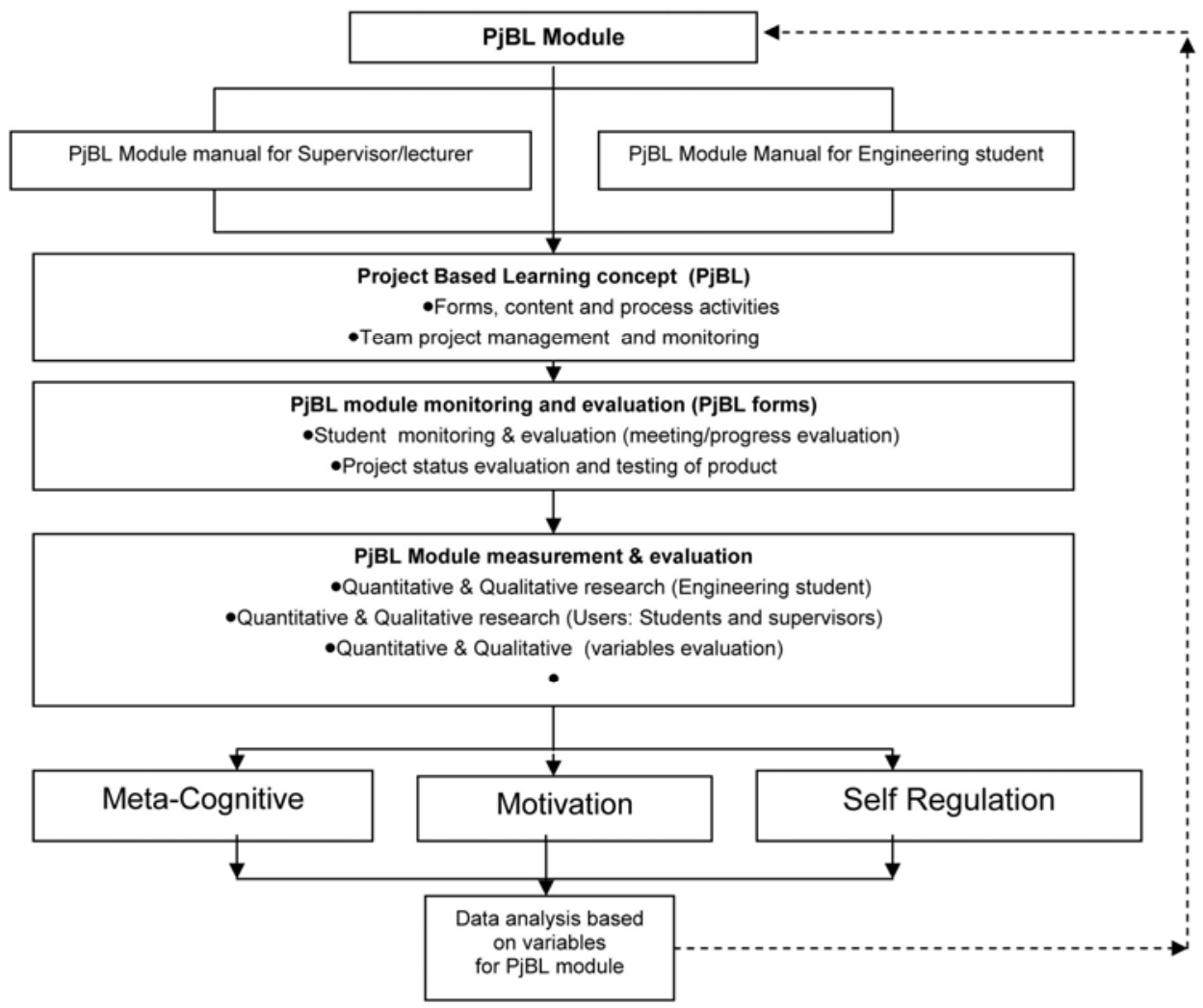

Figure 4. Implementation procedure for PjBL module development 